\title{
Okul Öncesi Eğitimde Bir Kültür Aktarımı: Millî Oyunlar
}

\author{
Dr.Döndü Neslihan BAY(Öğr. Üyesi) \\ Eskişehir Osmangazi Üniversitesi-Türkiye \\ bayn@ogu.edu.tr
}

\begin{abstract}
Özet:
Araştırmanın amacı, okul öncesi eğitim programı kapsamında hazırlanan millî oyun etkinliklerinin çocuklar üzerindeki etkisini ortaya koymaktır. Bu amaç doğrultusunda çocukların (i) bildikleri millî oyunları, (ii) oynamayı en çok sevdikleri, (iii) oynamakta en çok zorlandıkları ve (iv) aileleriyle oynadıkları millî oyunların ortaya konulması alt amaçları oluşturmaktadır. Yeni bir uygulamanın gerçekleştirilmesi ve bu uygulamaya ilişkin değerlendirmenin yapılması sürecini kapsayan işbirlikçi eylem araştırması ile millî oyunların okul öncesi eğitim programı içinde uygulanmış ve çocuklar üzerindeki etkisi değerlendirilmiştir. Araştırmaya 60 çocuk katılmıştır. Araştırma sürecinde 38 farkı millî oyun bir yıllık eğitim süresince uygulanmıştır. Çocuklarla görüşme yapılmıştır. Araştırmada çocukların istekle oyunları oynadıklarının gözlenmesi, ögretmenlerin olumlu değerlendirmeleri ve çocukların millî oyunları çoğunlukla ifade etmeleri, kültürel aktarımın gerçekleştiğini göstermektedir. Çocukların en çok sevdiği oyunlar "misket" ve "saklambaç"; oyunlar sevmelerinin nedenlerini "eğlenmeleri" ve "oyunların oynanış şekli"; en çok zorlandıkları oyun "beş taş" ve "saklambaç"; aileleriyle de bazı millî oyunları oynadıkları sonuçlarına ulaşılmıştır. Sonuçlar değerlendirildiğinde millî oyunların çocukların ilgi ve algıları üzerinde etkili olduğu görülmüştür.
\end{abstract}

Keywords: Millî, oyun, kültür, eğitim, okul öncesi, anaokulu

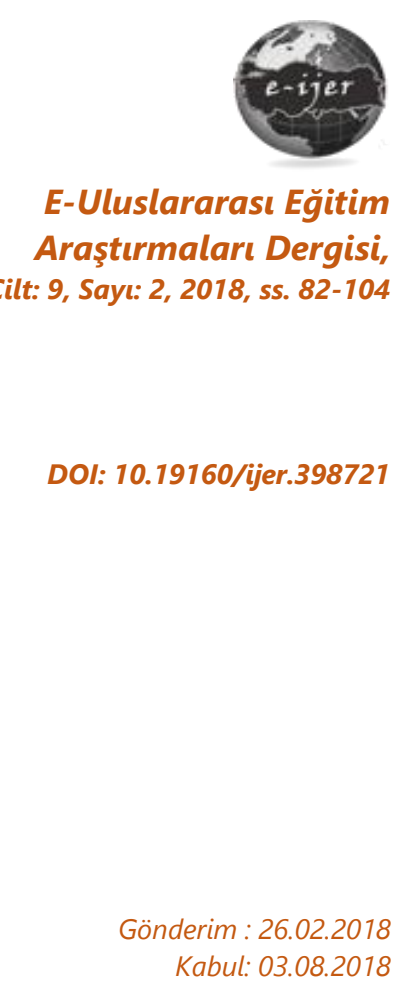

\section{Önerilen Atıf}

Bay, D.N. (2018). Okul Öncesi Eğitimde Bir Kültür Aktarımı: Millî Oyunlar E-Uluslararası Eğitim Araştırmaları Dergisi, Cilt: 9, Sayl: 2, 2018, ss. 82-104, DOI: 10.19160/ijer.398721 


\section{Giriş}

Okul öncesi eğitim, çocuklarda sosyal, iletişim, estetik, algısal ve düşünme becerileri gibi bir çok beceriyi geliştirmenin yanı sıra kendisinin ve kültürünün farkında olma yeterliliğini de geliştirmeyi hedeflemektedir (Senemoğlu, 1994). Çocuğun kültürü, ortaya koyduğu hal, tavır, davranış ve duygularıdır. Çocuğun kültürünün dışa vurumu ise oyunlar yoluyla olmaktadır (Oksal, 2004). Çocuklardaki beceriler ve kültürel farkındalığın gelişebilmesi için oyun yoluyla öğretime intiyaç vardır (Senemoğlu, 1994). Bu yaklaşımda oyun, amaç değil araç olarak görülmektedir. Bir başka ifadeyle eğitimin içinde oyunun olması gerektiği üzerine durulmaktadır (Güneş, 2015). Russ'a (2004) gore çocukların oyun oynama sürecinde öğrenme kanallarını aktive eden, yaratıcı düşünme, problem çözme, başa çıkma ve sosyal davranışlar gibi, oyunlarda bilişsel, duyuşsal ve kişilerarası süreçlerin uyarlanması için önemli olan uyum becerileri gelişmektedir. Oyun yoluyla öğretimin gerekliliğini anlayabilmek için öncelikle oyunun tanımına ve içeriğine bakmak gerekmektedir. Çocukların dış dünyasında nesne ve kişileri, iç dünyasında düşünce ve duygularını anlamlandırdığı oyun, zevk için yapılan, eğlenceli ve kendiliğinden ortaya çıkan bir özelliğe sahiptir (Artar, 2004; Gökşen, 2014).

Oyunun farklı tanımları da yer almaktadır. Froebel'e göre oyun, insanların geliştiği büyüdüğü ve olgunlaştığı, yeteneklerini geliştirdiği hayatın bir çekirdeğidir (Bayrak, 1998). Yörükoğlu'na (2004) göre oyun, çocukların baş uğraşısı ve en önemli işidir. Cirhinlioğlu'na (2001) göre oyun, çocuğun bütün gelişim alanlarını destekleyen önemli bir araçıır. Yardımcı ve Tuncer'e (2002) göre oyun, çocuğun hayatının temel unsurlarındandır. Fromberg ve Bergen 'e (2006) gore oyun çocuğun ruhunun ifadesini ve özelliklerini tanımlamada bir anahtardır. Tanımlarda da görüldüğü gibi oyun, çocuğun her konumda ihtiyaç duyduğu hayatının bir gayesi olarak kendini göstermektedir (Gökşen, 2014).

Oyun sayesinde çocuğun bütün gelişim alanları (psikomotor, dil, bilişsel, sosyalduygusal) ve özbakım becerileri desteklenmektedir (Fırat, 2013; Öncü ve Özbay, 2014; Güneş, 2015). Dansky (1999) çocuklara oyun öğretme çalışmalarını gözden geçirdiği araştırmasında, çocuklara oyunlar öğretilmesi sonucunda çocukların rol oynamaya yönelik yetenek ve hayal güçlerinde artış olduğunu bulmuştur. Kerkez, (2006) araştırmasında uyguladığı oyun ve egzersiz programının olumsuz çevre koşullarına maruz kalan dezavantajlı çocukların fiziksel ve motor gelişimleri üzerinde etkili olduğunu ortaya çıkarmıştır. Benzer şekilde Kuru (2012) araştırmasında 14 hafta uyguladığı oyun programı sonrasında çocukların koşma, top atma, top tutma, ileri ve yukarı sıçrama gibi motor becerilerinde gelişme olduğunu belirlemiştir. Dil gelişimine etkisini ortaya koymaya yönelik Gözalan ve Koçak'ın (2014) araştırmasında, oyun programının uygulanması ile çocuklarının kelime bilgi düzeylerinin arttığı görülmüştür. Oyun oynarken çocuğun kendini oyun içindeki rolüne göre ifade etmesi, oyun içinde geçen sayışmaca, tekerleme ve şarkıları söylemesi, sadece kelime dağarcığını genişletmemekte, aynı zamanda konuşma, dinleme ve anlama becerilerini de geliştirmektedir (Girmen, 2012; Fırat, 2013). Kaya (2010) özel gereksinimli çocuklara uyguladığı oyunla müdahale programı sonrasında çocukların bilişsel gelişimlerinde ilerleme olduğunu ortaya koymuştur. Bilişsel gelişime yönelik yapılan Türkoğlu ve Uslu'nun (2016) araştırmasında da 12 hafta boyunca oyun temelli bilişsel gelişim programı uygulanmış ve çocukların bilişsel gelişimlerinde anlamlı artış olduğunu belirlenmiştir. Oyunun çocuğun sosyal ve duygusal gelişimi üzerine Durualp ve Aral'ın (2010) araştırmasında 8 hafta uygulanan oyun temelli sosyal beceri eğitimi programının çocukların sosyal gelişimlerini ileri düzeyde arttırdığı saptanmıştır. Görüldüğü gibi oyun çocukları bütünsel olarak gelişimlerini desteklemektedir. 
Aral'a göre (2000), oyunların bir diğer önemli etkisi ise çocukların eğitiminde kazanılan bilginin kuşaktan kuşağa taşınmasını sağlamasıdır. Bu bağlamda oyun değerlendirildiğinde, çocuğun hayata hazırlanmasını sağlayan informal bir eğitim alanıdır (Gökşen, 2014). Oyun çocuğun kendisi için gerekli olan bilgi ve becerileri çocuğun yaparak yaşayarak öğrenmesini sağlayan en doğal öğrenme aracıdır. Hayata dair kavramlar ve kavramların içinde barındırdığı beceriler oyun içinde gelişmektedir (Kaytez ve Durualp, 2014). Bu kavramları ve becerileri kazandırmak aynı zamanda eğitimin de temel hedefidir. Eğitim sürecinde kazandırılmaya çalışılan iletişim kurma, paylaşma, iş birliği ve yardımlaşma, birlikte problemleri çözebilme gibi bir çok beceri oyunun oynanma sürecinde çocukların kullandıkları beceriler arasındadır (Cirhinlioğlu, 2001; Sevinç, 2004; Girmen, 2012; Fırat, 2013; Gökşen, 2014; Öncü ve Ünlüer, 2014, Güneş, 2015; Özdemir, 2015; Özden Gürbüz, 2016). Oyun oynarken bu becerileri kullanarak çocuğun sosyal yaşama uyum sağladığı ve çevresiyle uzlaştığı görülmektedir (Anılan, Girmen, Öztürk ve Koçkar, 2004; Aral, 2000). Bu sayede çocuğun kendine güveni ve sosyal etkileşimi artmaktadır (Güneş, 2015).

Aynı zamanda çocuklar oyunlarında sevinç, kıskançlık, üzüntü, sevgi gibi bir çok duygusunu da sınayıp deneyimlemektedir. Bütün bu etkileşim ve deneyimler sonucunda çocuğun kendini tanıdığı, benlik algısıyla birlikte kimliğini de oluşturmaya başladığı önemli bir süreç yaşanmaktadır. (Cirhinlioğlu, 2001; Yörükoğlu, 2004). Çocuklar bu süreç içinde kendilerine dışarıdan belirledikleri modelleri referans olarak alarak kimliklerini, ait oldukları toplumların değerleri ile açıklama çabası içindedirler (Bayat, 2003). Dolayısıyla okul öncesi dönemde çocuk, oyun oynayarak kişiliğin yanı sıra yaşadığı toplumun değerlerini de kazanmaya başlamaktadır (Cirhinlioğlu, 2001). Toplum çocuğun fiziksel geliçiminin yanı sıra kültürel olak sosyal, duygusal, ahlaki ve entellektüel beklentilerini de çocuğa kazandırma çabası içindedir. Ailenin ve toplumun beklentilerini yerine getirebilmeleri için çocuklara gerekli eğitim desteğini vererek yardım edecek olan yine toplumun kendisidir (Brooker, 2010). Gelişimsel süreç içinde çocuğun toplumda bir çok kişi ile etkileşime girdiği ve bu kişilerden aldığı geri dönütler sonucunda çıkarımlarda bulunarak toplumun bireyi olma yolunda ilerlediği görülmektedir (Bayat, 2003). Bir diğer ifade ile, çocuk toplumun değerlerini kazandığı ölçüde topluma da kendisini kabul ettirmektedir (Çolak, 2009).

Toplumun, dolayısıyla da o toplumu oluşturan milletin bir üyesi olabilmek için bazı unsurların bilincinde olmak gerekmektedir. Toplumları millet yapan ve milletin devamlılığını sağlayan en önemli iki unsur "ortak bir geçmişe sahip olmak" ve "ülkü birliği"dir. Oyunların millet üzerindeki etkisine bakıldığında oyunun bireyin hayatında ortak yaşantıyla birlikte ülkü birliğini sağladığı görülmektedir (Gökşen, 2014). Huizinga, ortak yaşantı sonucu ortak bir geçmişi oluşturan oyunun, kültürün temeli olduğunu belirtmiştir. Çocuk, oyun içinde sözlü ve sözsüz kültürel iletişim kurar ve bu iletişimle birlikte kültürünü bilir, tanır ve dener (Özdemir, 2006). Bu nedenle kültürel çocuk oyunları, 2003 yılında UNESCO tarafından somut olmayan kültürel mirasın bir parçası olarak görülmüş ve "Somut Olmayan Kültürel Mirasın Korunması Sözleşmesi"nde korunması gerektiği belirtilmiştir (Toksoy, 2010). Ortaya çıkan bu gereklilik, oyunların kültürün önemli bir parçası olarak görülmesi gerektiğini göstermektedir.

Bir toplumu doğal gelişim ve değişim süreci içinde şekillendiren, bu sayede o toplumu diğer toplumlardan ayıran maddi ve manevi değerlerin tamamı, kültür olarak tanımlanmaktadır (Türkçe Sözlük, 1998). Bir diğer ifade ile kültür, bir milletin tarih süreci içerisinde ortaya koyduğu, geliştirdiği ve deneyimler ile sağlamlaştırıp kesinleştirdiği değerlerin bütünü olarak da tanımlanmaktadır (Özdemir, 2015). Dolayısıyla kültür, inanç, gelenek, töre gibi olgularla toplumun yaşam süreci içinde kendini göstererek toplumun hafızasında yer eden dinamik bir yapıdır. Dinamik olması kültürün değişim ve dönüşüme açık bir yapıda olduğunun da bir göstergesidir. Bu durum kültürdeki güncelleşmenin gereğini ve güncelleşme kapsamında var olana uyum ve var olanı korumanın önemini ortaya çıkarmaktadır. Gerekli olan uyum ve koruma 
sağlanamadığında ise toplumun birliği zayıflamakta ve kültürün varlığı tehdit edilmektedir (Malinowski, 2000). Bir milleti millet yapan ve onu diğer milletlerden ayıran millî kültür, küresel kültür olarak değişim sürecine girmeye başlamıştır. Atatürk "Kati olarak bilinmelidir ki, Türk milletinin millî dili ve millî benliği bütün hayatında hakim ve esas olacaktır." ifadesi ile millî kültürün önemini vurgulamıştır. Bu bağlamda millî kültürün ve kimliğin korunması yönünde önlemlerin alınması ve millî kültüre sahip çıkma yönünde bilinçli olunması gerektirmektedir (Mahiroğulları, 2005). Çünkü kültür, geçmişi şu ana taşyarak geleceğe yön vermektedir (Neuliep, 2012).

Kültürü ve onun içinde yer alan oyunları korumanın her geçen gün daha da zorlaştığı, bir gerçektir. Günümüzde toplumlardaki değişimlere bakıldığında, modern şehir hayatı ile birlikte teknoloji ve medya kullanımının artmasıyla, kültürün diğer unsurlarıyla birlikte oyunların da unutulmaya başlandığı görülmektedir (Toksoy, 2010; Özden Gürbüz, 2016; Peksoy, 2017). Çocuklar akranlarılla oyun oynamak yerine teknolojinin getirdiği bilgisayar ya da akıllı telefonlardaki sanal oyunları oynamayı tercih etmeye başlamıştır (Özdemir, 2006)

Türkiye açısından bakıldığında batı ülkelerinde olduğu gibi çocuk oyunlarının modernleşme sürecinden geçtiği, bu nedenle geleneksel özelliklerini de gitgide yitirmeye başladığı görülmektedir. Okul öncesi eğitim kurumlarında oyunlar modern olarak görülen oyunların oynatılması tercih edilmektedir (Onur ve Güney, 2004). Millî oyunların çocuklar tarafından bilinmemesi ve oynanmaması, çocuklarda millî benliğinin oluşumunu olumsuz etkilemektedir (Fırat, 2013; Özden Gürbüz, 2016). Oysaki oyunlar, toplumların bir görünümüdür ve o topluma özgüdür. Dolayısı ile millî oyunlar, ait olduğu toplumun kültürünü ve düşünme biçimini yansıtmaktadır (Güneş, 2015). Özdemir (2006) çocuk oyunlarının millî birliktelik açısından önemini "Türkiye'nin hemen her yerinde küçük farklılıklara rağmen aynı türden oyunların oynandığı tespit edilmiştir. Bu aynılığın oynanma biçimlerinin yanında oyunların sözel unsurları olan oyun terimleri ve oyun formüllerine dek uzanması anlamlıdır. Bu bakımdan aynı kültürel dokuya ve motiflere sahip olan toplumda, çocuk oyunlarının birleştirici niteliğinin varlığı yadsınamaz." sözleriyle vurgulamıştır. Bu oyunların oynanmaması ve bilinmemesi, o toplumu diğer toplumlardan ayıran özelliklerin de yitip gitmesi anlamına gelmektedir.

İlgili araştırmalara bakıldığında çocukların oyun algılarındaki ciddi değişim görülmektedir. Akçay ve Özcebe'nin (2012) okul öncesi eğitim alan çocuk ve ailelerinin bilgisayar oyunu oynama alışkanlıklarını ortaya koymaya yönelik yaptıkları araştırmada çocuklarının \%44.1'inin bilgisayar oyunu oynadığı görülmüştür. Koçyiğit ve Baydilek-Başara (2015) okul öncesi dönemdeki çocuklarının oyun algılarını araştırmış ve çocukların genelde evde yalnız başlarına oyun oynadıklarını ortaya koymuştur. Çocukların yalnız olduklarında ise bireysel oyunlarının yanı sıra bir ve birden fazla teknolojik aletle en az bir saat olmak üzere zaman geçirdikleri Gündoğdu ve arkadaşları (2016) tarafından tespit edilmiştir. Çocuğun en önemli uğraşı olan oyunun teknolojinin etkisi ile değiştiği, geleneksel oyuncak ve oyunların günümüz çocukları tarafından her geçen gün biraz daha bilinmediği ve oynanmadığı görülmektedir (Cengiz, 1997; Başal, 2007; Esen, 2008).

Oysaki çocuğun ilgileri, beğenileri ve yeteneklerinin geliştiği, dolayısıyla da kişiliğinin gelişmeye başladığı okul öncesi dönem, kültürü aktarımının başladığı kritik bir dönemdir (Özdemir, 2015). Sanal bir dünyada büyümeye başlayan çocuklar için kültür, eğitimin bir parçası olarak görülmeli ve eğitim kurumları üzerine düşen görevi yapmalıdır (Toksoy, 2010; Akyüz, 2016). Nesiller boyunca aktarımla çocuklara kazandırılan oyunlar, geçmiş ve gelecek arasında kültür köprüsü kurarak kültürel aktarımı sağlamaktadır (Oksal, 2004; Fırat, 2013). Türk dünyası olarak oyunlar değerlendirildiğinde coğrafi farklılıklar olmasına rağmen düşünme ve ifade etmedeki birliktelik birçok gelenekte olduğu gibi oyunlarda da yer almaktadır (Esen, 2008; Gökşen, 2014). Dolayısıyla birlikteliğin devamlılığı için kültür aktarımını sağlayacak olan millî 
oyunların, okul öncesi eğitim süreci içinde verilmesi gerekmektedir (Başal, 2007; Fırat, 2013; Öncü ve Ünlüer, 2014; Özden Gürbüz, 2016). Bu bağlamda hem kültürel mirasımız olan ve hem de eğitimde verimlilik için esas unsur olan oyunların, yaratıcı değerlendirmelerle millî bir eğitim malzemesi haline getirilmesi gerekmektedir (Sağlam, 1997). Aksi taktirde kültür, yok olmaya mahkum olacaktır (Akyüz, 2016).

Sonuç olarak oyun, çocukların diğer gelişim alanlarının yanı sıra kültürel gelişimleri açısından da önemli bir yere sahiptir. Kültürel oyunlar, küçük yaşta kültürel aktarımı sağlayarak hem kültürel mirası korumayı hem de çocukların topluma ait bir birey olma yolunda kültürüne uygun kimlik kazanımlarını sağlamaktadır. Bu nedenle kültürel oyunların millî eğitim sisteminde millî oyunların kazandırılması hedefiyle eğitim kademelerinin ilk basamağı olan okul öncesi eğitim kapsamında verilmesi gerekmektedir. Ortaya çıkan bu gereklilik araştırmanın konusunu oluşturmuştur.

Araştırmanın amacı okul öncesi eğitim programı kapsamında hazırlanan kültürel değerlerin bir taşıyıcısı olan millî oyun etkinliklerinin çocuklar üzerindeki etkisini ortaya koymaktır. Bu amaç doğrultusunda bir yıllık eğitim-öğretim sürecinde uygulanan millî oyun etkinlikleri sonrasında çocukların (i) bildikleri millî oyunları, (ii) oynamayı en çok sevdikleri, (iii) oynamakta en çok zorlandıkları ve (iv) aileleriyle oynadıkları millî oyunların ortaya konulması alt amaçları oluşturmaktadır.

\section{YÖNTEM}

Nitel araştırma çeşitlerinden işbirlikçi eylem araştırması yapılmıştır. Işbirlikçi eylem araştırması yeni bir uygulamanın gerçekleştirilmesi ve bu uygulamaya ilişkin değerlendirmenin yapılması sürecini kapsamaktadır (Yıldırım ve Şimşek, 2013). Bu araştırmada da millî oyunların okul öncesi eğitim programı içinde bir yıl süresince fen, matematik, müzik gibi farklı etkinliklerle bütünleştirilmiş etkinlik olarak uygulandıktan sonra oyun etkinliği olarak uygulamaları gerçekleştirilmiş ve kültürel oyunların çocuklar üzerindeki etkisi değerlendirilmiştir. Değerlendirmede gözlem, görşme ve doküman incelemesi yöntemleri kullanuılmıştır.

\section{Katılımcılar}

Tipik durum örneklemesi, sıra dışı olmayan, ortalama düzeyde bir örneklemin belirlenmesidir (Büyüköztürk, Çakmak, Akgün, Karadeniz ve Demirel, 2017). Araştırmada tipik durum örneklemesine göre ortalama düzeyde bir kurum anaokulu belirlenmiştir. Belirlenen anaokulunda bulunan 4 yaş grubundan 3, 5 yaş grubundan 3 sınıf olmak üzere 6 sınıf katılımcı sınıflar olarak belirlenmiştir. Bu sınıflarda $32 \mathrm{kız}$ ve 28 erkek olmak üzere toplam 60 çocuk araştırmaya katılmıştır. Çocuklardan 16 kız, 14 erkek olmak üzere 30 çocuk 4 yaş grubunda, 16 kız, 14 erkek olmak üzere 30 çocuk da 5 yaş grubundadır.

\section{Araştırmanın Aşamaları}

I. Araştırmada ortak kültürel mirasa sahip olduğumuz ilgili alanyazına dayalı olarak belirlenmiş, oyunların oynanış tanımları detaylandırılarak düzenlenmiştir. Belirlenen oyunların tanımları okul öncesi öğretmenleri ile paylaşılmış, bazı oyunların oynanışı öğretmenlere uygulamalı olarak anlatılmıştır.

II. Eğitim-öğretim yılının tamamını kapsayacak şekilde haftalık plan yapılmış ve güz döneminde haftada iki, bahar döneminde ise okulun etkinlikleri açısından daha yoğun bir dönem olduğu için haftada bir olmak üzere oyunların uygulanma çizelgeleri oluşturulmuştur. 
III. Her bir oyun için okul öncesi eğitim programına uygun olarak bütünleştirilmiş etkinlik planları hazırlanmıştır. Örneğin, beş taş oyunu bütünleştirilmiş oyun ve matematik etkinliği olarak hazırlanırken, körebe oyunu bütünleştirilmiş fen ve oyun etkinliği olarak planlanmıştır. Hazırlanan planlar hafta başında öğretmenlerle paylaşılmış ve uygulama öncesinde gerekli gördükleri düzenlemeleri yapabilecekleri belirtilmiştir. Haftanın başında ilgili materyallerin hazırığı kontrol edilmiş, aşık, sapan, topaç gibi bulunmayan materyaller ise araştırmacı tarafından temin edilmiştir. Etkinlikler uygulandıktan sonra öğretmenler çocukların istekleri ve kendi planlamaları dahilinde yıl içinde oyunları sıklıkla oynatmıştır.

IV. Her haftanın sonunda en az bir saat değerlendirme toplantısı yapılmış ve öğretmenlerin görüşleri alınmıştır.

V. Öğretmenlerin oyun etkinliklerini uygulamalarından sonra öğretmenlerden öğretmen, program ve çocuk açısından yaptıkları değerlendirme raporları alınmış ve uygulamalar hakkında görüşülerek bilgi alınmıştır.

VI. Araştırmacı tarafından hazırlanan etkinlik planlarının haricinde öğretmenler, çocukların oyunları öğrenme düzeyleri ve istekleri doğrultusunda oyunları tekrar oynatmıştır.

VII.Bahar döneminin sonunda çocukların millî oyunlar hakkındaki düşünceleri açık uçlu sorularla görüşme yapılarak alınmıştır.

\section{Araştırmada Geliştirilen Etkinlik Planları}

Okul öncesi eğitim programında etkinlikler tek veya bütünleştirilmiş olarak ele alınmaktadır. Bütünleştirilmiş etkinlik birden fazla etkinliğin uygun geçişler sağlanarak bir araya getirilmesi ile oluşturulmaktadır (MEB, 2013). Etkinlikler birbirinden ayrı değil iç içe geçmiş olmalıdır. Araştırmada millî oyunların sadece oyun etkinliği içinde değil fen, matematik, sanat, müzik diğer etkinlikler içinde de kullanılabileceği uygulamalı olarak gösterilmiştir. Millî oyunlarımız arasında yer alan körebe oyunu ile fen, kulaktan kulağa ile dil ya da mendil kapmaca ile matematik etkinliklerinin yapılabildiği bütünleştirilmiş etkinlik planları, okul öncesi öğretmenlerine hazırlanarak verilmiştir. Bazı etkinlik plan örnekleri ekte sunulmuştur.

\section{Uygulama Süreci}

Uygulamaya başlamadan önce, çocukların geçmişte ebeveynleri tarafından oynanmış olan millî oyunlar hakkında bilgi ve deneyim kazanacakları herhangi bir uygulama yapılmadığı öğretmenler tarafından teyit edilmiştir. Çocukların millî oyunlara yönelik farkındalıklarını oluşturmak amacıyla hazırlanan bütünleştirilmiş millî oyun etkinlikleri haftalara göre belirlenen planlama doğrultusunda öğretmenlere verilmiştir. Öğretmenlere planları aldıktan sonra sınıflarındaki çocukların ilgi ve intiyaçları doğrultusunda planlar üzerinde düzenleme yapabilecekleri belirtilmiş ve o hafta içinde belirlenen millî oyun etkinliğini uygulamaları istenmiştir. Öğretmenlerin bilmediği bazı oyunlar, öğretmenlere uygulamalı olarak anlatılmıştır. Etkinliklerin uygulaması sonrasında öğretmenlerle yapılan görüşmelerde değerlendirmeler alınmıştır. Uygulama sürecinde çocuklar tarafından başlangıçta oynarken zorluk çekilen bazı oyunların yıl içinde daha başarılı oynanmaya başlandığı, çocukların oyuna yönelik ilgi ve algılarının süreçte geliştiği gözlenmiştir.

Öğretmenler günlük eğitim akışında yer alan oyun zamanında sıklıkla çocukların millî oyun oynamak istediklerini belirtmiştir. Millî oyunların aktarımı için hazırlanmış olan etkinlik planlarının haricinde, yıl içinde çocukların ilgi ve istekleri doğrultusunda oyunlar sıklıkla tekrarlanarak oynanmıştır. Öğretmenlerin etkinlik planlarında yazdıkları değerlendirmelere, öğretmenlerle yapılan görüşmelere ve araştırmacı gözlemlerine dayalı olarak, çocukların millî oyunları 
oynamaya olan istekliliklerindeki artışın, çocuğun oyunu ne kadar anlayabildiği, ne kadar başarabildiği ve oyunda ne kadar eğlenebildiği ile ilgili olduğu düşünülmektedir. Aşağıda bazı etkinliklerde çekilen fotoğraflar yer almaktadır.

\section{Resim 1. Topaç}

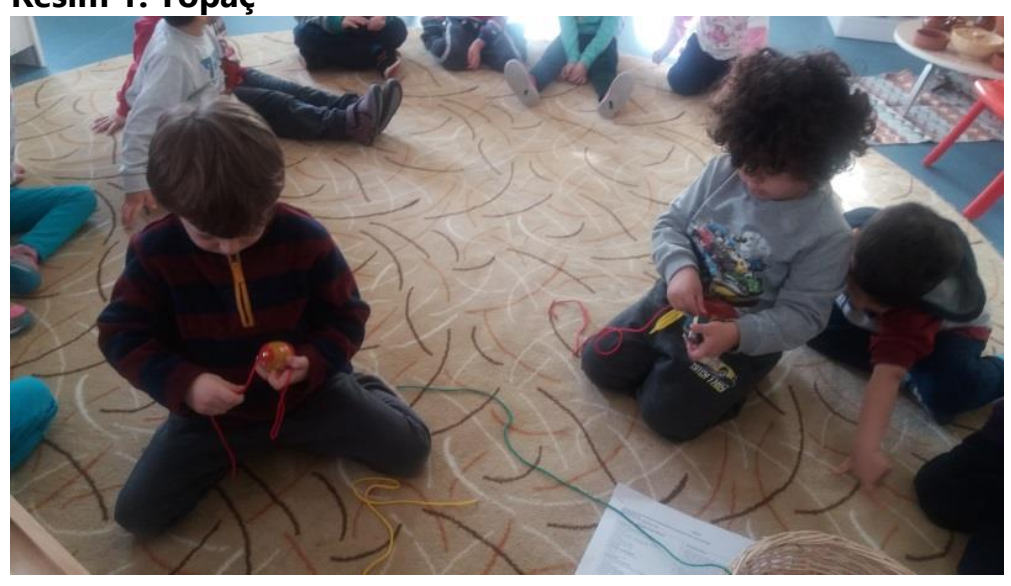

\section{Resim 2: Misket}

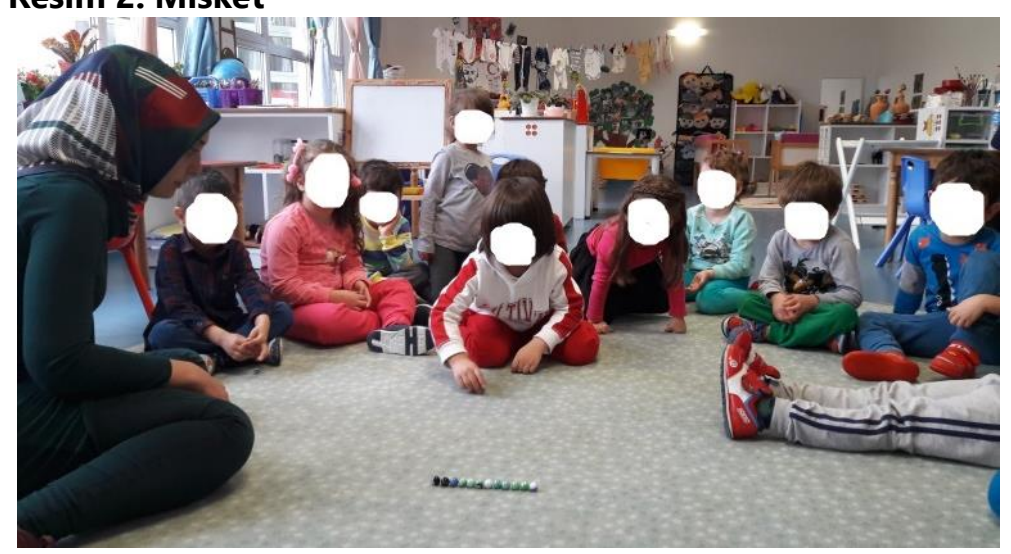

Resim 3. Halat çekme

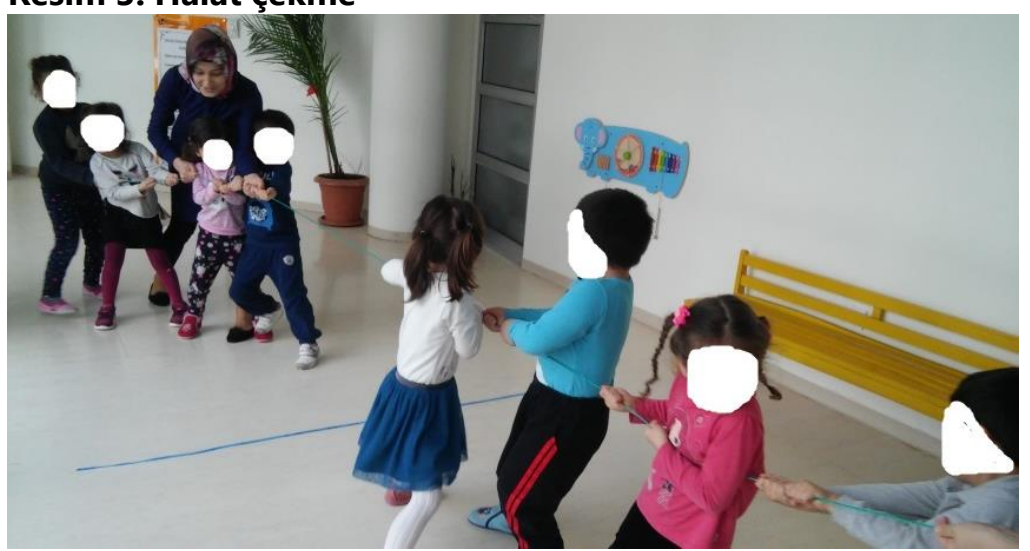




\section{Resim 4. Çuval Yarışı}

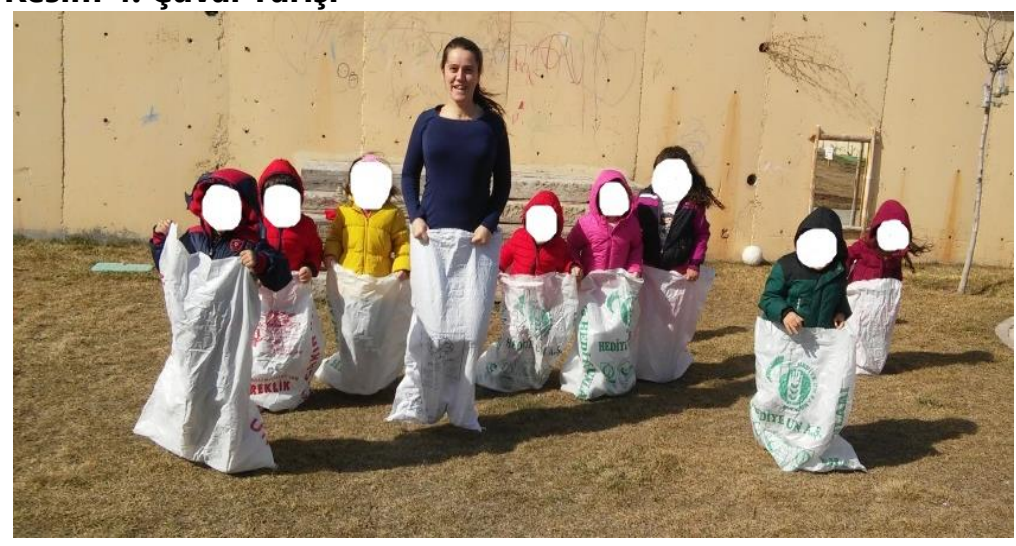

\section{Resim 5. Mendil Kapmaca}

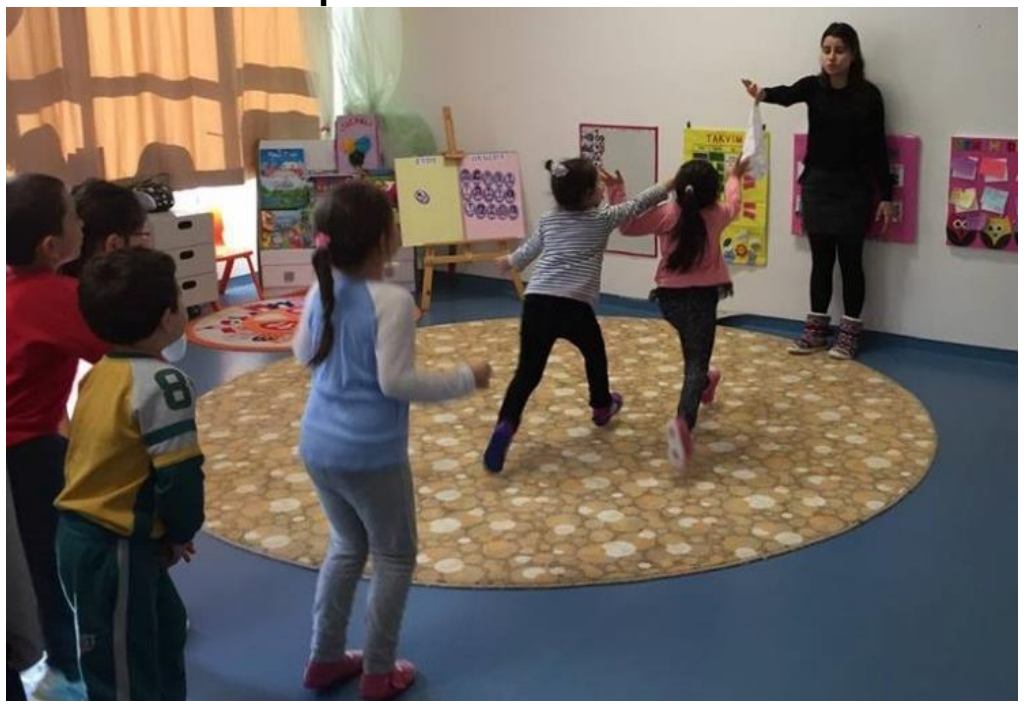

\section{Resim 6. Așık Atma}

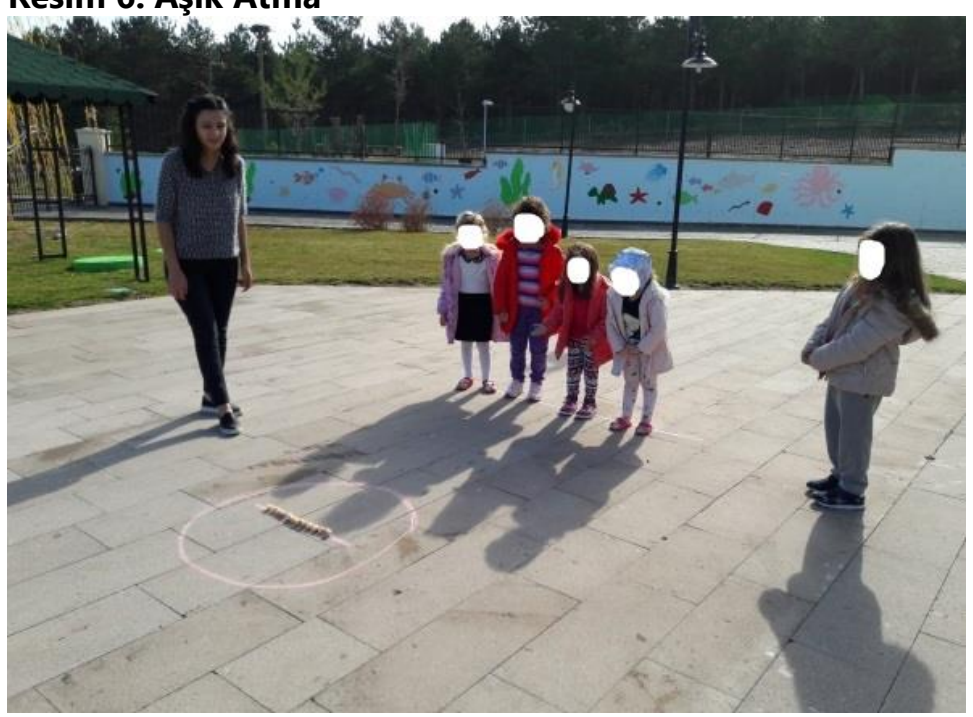




\section{Verilerin toplanması}

Araştırmada uygulamanın doğru bir şekilde ilerlediği her hafta öğretmenlerle cuma günü yapılan toplantı ile değerlendirilmiştir. Öğretmenlerden planların değerlendirmeleri alınmış ve çocukların etkinliklerinin gözlemleri yapılmıştır. Millî oyunların tamamının uygulanması sonrasında, dört açık uçlu soru her bir çocuğa öğretmenler tarafından oyunların çocuklar üzerindeki etkisini ortaya koymaya yönelik sorulmuş ve çocukların cevapları not edilmiştir. Elde edilen veriler kodlanmış ve ilgili sorular altında temalar oluşturulmuştur.

\section{Geçerlik ve Güvenirlik}

Nitel araştırmalarda araştırmacının gözlem yaptığı ortamda geçirdiği süreyi artırması, araştırmacının ortam üzerindeki olabilecek etkisini azaltacak ve ortam doğal haline dönüşecektir. Doğal ortamda gerçekleşen araştırmanın güvenirliği artacaktır (Yıldırım ve şimşek, 2013). Araştırmada bir eğitim öğretim yılını kapsayacak şekilde uzun süreli etkileşim gerçekleştirilmiştir. Bu süreçte etkinliklerin uygulanma süreci gözlenmiş, birebir gözlemin yanı sıra okulun kamera kayıtlarından takip edilmiş ve uygulamalara yönelik fotoğraf, materyal ve etkinlik planlarının dönütleri incelenmiştir.

Bir diğer geçerliği ve güvenirliği sağlayan unsur ise uzman incelemesidir. Uzman araştırmacıya önerilerde bulunarak araştırma sürecinin güvenilir olmasına katkıda bulunur (Yıldırım ve Şimşek, 2013). Araştırma sürecinde geliştirilen etkinlik planları için iki alan uzmanından görüş alınmış; uzmanların görüş ve önerileri doğrultusunda planlar düzenlenmiştir. Ayrıca planlar uygulama öncesinde öğretmenlerin incelemelerine sunulmuş, ortak olarak düzeltilmesi gereken hususlar olduğunda gerekli düzeltmeler yapıldıktan sonra uygulamaya konulmuştur.

Araştırmada elde edilen verilerin oluşabilecek öznel yargıları ortadan kaldırmak amacıyla katılımcı teyidinin alınması sonuçların gerçeği temsil etme olasılığını arttırmaktadır (Yıldırım ve Şimşek, 2013). Bu bağlamda her uygulama haftasının son gününde öğretmenlerle "teyit toplantısı" yapılmış ve uygulamalar değerlendirilmiştir.

\section{BULGULAR}

Araştırmada Türk dünyasında oynanan oyunlar arasından 38 millî oyun, bir yıllık eğitim-öğretim süreci içinde bir kurum anaokulunda farklı etkinliklerle çocuklara aktarılmaya çalışılmış ve okul öncesi eğitim programı kapsamında uygulama yapılmıştır. Uygulama yapan öğretmenler tarafından etkinlik planlarının sonunda yaptıkları değerlendirmelerde istenilen kazanım ve göstergelere ulaşıldığının belirtilmesi, çocukların millî oyunları oynamaya ilgi ve istekli olduklarının ifade edilmiş olması ve eğitim öğretim yılı içinde araştırmacının doğrudan uygulama sürecinde çocuklar üzerinde yapmış olduğu gözlemler, millî oyunların okul öncesi eğitimde aktarımının gerçekleştiğini; bu aktarımla birlikte çocukların kültür gelişimlerinin yanı sıra diğer gelişim alanlarının da desteklediğini göstermiştir. Bir başka ifadeyle, okul öncesi eğitimde millî oyunlar, program dahilinde kolaylıkla uygulanabilmekte ve bu uygulamalarla çocukların bilgi, beceri ve gelişimleri desteklenebilmektedir.

Millî oyunların uygulanması sonucunda oyunların çocuklar üzerindeki etkisini ortaya koymak amacıyla yapılan araştırmada çocuklara aktarılan 38 millî oyundan beş yaş grubu çocukların 24 (\%63) tanesinin, dört yaş çocukların ise 32 (\%84) tanesinin adını sorulara verdikleri cevaplarda söyledikleri görülmüştür. Millî oyunların çocuklar üzerindeki etkisini ortaya koymaya yönelik belirlenen alt amaçlar doğrultusunda bulgular aşağıda verilmiştir. 


\section{(i) Çocukların bildikleri millî oyunlar}

Çocuklara geçmişte dedelerinin/ninelerinin hangi oyunları oynamış olabileceği sorulmuş ve verilen cevaplar doğrultusunda çocukların bildikleri oyunlar kodlanmıştır.

Beş yaş grubu çocuklar 13 farklı millî oyun ismi söylemiştir. Bu oyunlar, misket, 5 taş, topaç, aşık, ip atlama, körebe, seksek, bezirganbaşı, sapan, saklambaç, köşe kapmaca, lastik atlama, 3 taştır. Çocuklardan 4'ü millî oyun kapsamında yer almayan oyun isimleri (deve cüce, kağıt gemi, sandalye kapmaca, halk oyunu) söylemiştir. Çocukların söyledikleri oyunlardan en fazla söylenerek tekrar edilen millî oyun, 5 taş $(n=5)$ oyunu olmuştur. İkinci olarak ise üçer kez tekrar edilen topaç, sek sek ve aşık oyunları yer almaktadır.

Dört yaş grubu çocuklara bakıldığında 23 farklı millî oyun adının söylendiği ve beş yaş grubundaki çocukların adını söylediği 13 millî oyunun 3 taş oyunu haricinde tamamının adının bu yaş grubu tarafından ifade edildiği görülmüştür. Bu oyunlar, misket, 5 taş, topaç, aşık, ip atlama, körebe, seksek, bezirganbaşı, sapan, saklambaç, köşe kapmaca, lastik atlama, ip oyunu, istop, şapka, kedi-sıçan, uçtu uçtu, çelik çomak, evsiz tavşan, yüzük saklama, halat çekme, mendil kapmacadır. Bu oyunların içinde en çok tekrarlanan oyun topaç ve köşe kapmaca oyunları $(n=4)$ olmuştur.

\section{(ii) Çocukların oynamayı en çok sevdiği millî oyunlar}

Çocuklara geçmişte oynanan millî oyunlardan en çok hangisini oynamayı sevdikleri sorulduğunda, çocukların 38 millî oyun arasından en çok sevdiği oyunları seçmeleri beklenmiştir. Okul öncesi dönem için sorulan bu soru çocukların kendi kriterlerine göre değerlendirme yapmalarını gerektirmekte ve değerlendirme düzeyinde düşünme becerisini kullanmalarını sağlamaktadır. Soruya çocuklar birden fazla oyun adı söyleyerek değil sadece bir oyun adı söyleyerek cevap vermiştir. Beş yaş grubundaki çocuklar 16 farklı millî oyunun adını söylemiştir. Bu oyunlar, topaç, lastik atlama, 5 taş, bezirganbaşı, saklambaç, misket, evsiz tavşan, 3 taş, körebe, köşe kapmaca, çelik çomak, yüzük saklama, yağ satarım, aşık, köprü, seksektir. Bir önceki sorularda çocukların söylemiş oldukları millî oyunlara, bu soruda yağ satarım, evsiz tavşan, çelik çomak, yumurta taşıma, yüzük saklama ve köprü olmak üzere altı yeni oyun adı daha eklenmiştir. En fazla sevilen oyun olarak adı tekrarlanan oyun ise misket oyunu $(n=6)$ olmuştur.

Oynamayı en çok sevdikleri oyun sorusunun devamında sorulan neden sorusu, bilişsel düşünme basamaklarından analiz düzeyinde cevabın verilmesini gerektiren bir sorudur. Çocukların bu soruya cevap verebilmeleri için oyunları bilmeleri anlamaları, uygulamaları ve parçalara ayırarak neden sevdiklerini analiz etmeleri gerekmektedir. Çocukların verdikleri cevaplar ilgili temalar altında gruplandırılmıştır. Ortaya çıkan temalar:

Eğlence $(n=10)$

Oynanış şekli $(n=9)$

Materyal $(n=6)$

Kolay olması $(n=5)$

Çocukların en çok sevdikleri oyunu sevme nedenlerine bakıldığında en başta eğlenmeleri ve oynanış şekilleri olduğu görülmektedir. Oyunları neden sevdiklerinin diğer nedenler ise oynanış şekli, oyunda kullandıkları materyal (oyuncak) ve oyunun kolay olması olarak belirtilmiştir. Bazı çocukların ifadeleri aşağıda verilmiştir.

Ç: 5 Taş. Çünkü çok eğlenceli ve her sıkıldığımda oynayabiliyorum. 
Ç: 3 Taş. Kolay bir oyun olduğu için.

Ç: Aşık vurdurma. Aşıkları toplamak güzel.

Ç: Yağ satarım, bal satarım. Koştuğumuz için.

Dört yaş grubu çocuklarda en çok sevdikleri millî oyunlara bakıldığında 18 farklı millîl oyunun adını söyledikleri görülmektedir. Bu oyunlar, topaç, kuyruk yakalamaca, yağ satarım, misket, istop, saklambaç, körebe, sek sek, sapan, halat çekme, aşık, çelik çomak, 5 taş, 3 taş, evsiz tavşan, lastik atlama, birdirbir, kedi-sıçandır. Birinci sorudaki millî oyunlardan farklı olarak bu soruda birdirbir, kuyruk yakalama, yağ satarım, sapan ve 3 taş olmak üzere beş oyun daha adı söylenmiştir. En çok sevilen oyun olarak çocukların saklambaç oyununun $(n=4)$ adının tekrarladığı görülmüştür. Çocuklara neden bu millî oyunları oynamayı sevdikleri sorulduğunda verilen cevaplar ilgili temalar altında gruplandırılmıştır. Ortaya çıkan temalar:

Eğlence (12)

Oynanış şekli (8)

Seviyor (5)

Kolay olması (5)

Çocukların en çok sevdikleri oyunu neden sevdikleri sorulduğunda çoğunluğun eğlendiği için sevdiğini belirttiği görülmektedir. Diğer nedenler ise oynanış şekli, sevdikleri için ve kolay olduğu şeklinde belirtilmiştir. Bazı çocukların ifadeleri aşağıda verilmiştir.

Ç: Sapan. Çünkü atışı çok seviyorum.

Ç: Saklambaç. Çünkü saklanıyoruz, ebe yapıyoruz.

Ç: Sek sek. Çünkü o çok kolay.

Ç: 3 Taş. Çünkü 3 taşı yan yana getirmek çok eğlenceli.

Her iki yaş grubunun cevaplarına bakıldığında, çocukların oyunlara yönelik analiz düzeyinde düşünme sürecine sahip oldukları görülmektedir. Bu bağlamda düşünme süreçleri açısından bakıldığında cevapların içeriğinde çocukların oyunu bildikleri (bilme), kendi cümleleriyle ifade ettikleri (kavrama), oynadıkları (uygulama) ve sevme nedenini (analiz) belirttikleri görülmektedir.

\section{(iii) Çocukların oynamakta en çok zorlandıkları millî oyunlar}

Çocuklara oynamakta en çok zorlandıkları millî oyunlar sorulduğunda da benzer şekilde çocukların millî oyunlar arasında bir değerlendirme yaparak cevap vermeleri beklenmiştir. Çocuklar sevdikleri oyuna verdikleri cevap gibi bu soruya da sadece bir oyun adı söyleyerek cevap vermiştir. Beş yaş grubunda ki çocuklar 19 farklı oyun adı söylemiştir. Bu oyunlar, 5 taş, lastik atlama, sek sek, topaç, kuyruk yakalama, bız, saklambaç, evsiz tavşan, köşe kapmaca, ip oyunu, aşık, körebe, misket, yağ satarım, mendi kapmaca, istop, ip atlama, bezirganbaşı, çelik çomaktır. Beş yaş çocukları daha önce söyledikleri millî oyunlara bu soruya verdikleri cevaplarla bız, istop, kuyruk yakalama, mendil kapmaca, ip oyunu olmak üzere beş oyun eklenmiştir. Bir çocuk halk oyunları arasında yer alan çayda çıra oyununun adını, bir çocuk millî oyun listesinde yer almayan evcilik oyununun adını, bir çocuk da çömlekçilik adını söylemiştir. Bu millî oyunlar arasında en çok tekrarlanan ve dolayısıyla çocukların en fazla zorlandıklarını belirttikleri oyun 5 taş $(n=14)$ oyunu olmuştur. Diğer zorlandıkları oyunlar arasında ikinci olarak tekrar eden oyunlar arasında lastik atlama $(n=4)$ ve aşık $(n=4)$ oyunları yer almaktadır. 
Dört yaş grubunun verdiği cevaplara bakıldığında en çok zorlandıkları millî oyun sorusuna 16 farklı millî oyunun adını söyledikleri görülmektedir. Bu oyunlar, ip atlama, topaç, kuyruk yakalama, saklambaç, yakan top, körebe, sek sek, yağ satarım, mendil kapmaca, yerden yüksek, kazlar kazlar, kulaktan kulağa, yumurta taşıma, bezirganbaşı, lastik atlama, çelik çomak ve köprü oyunlarıdır. Çocuklar, bu soruya verdikleri cevaplarla daha önce söyledikleri millî oyun isimlerine dört yeni oyun adı daha eklemiştir. Bu oyunlar, yerden yüksek, kazlar kazlar, yumurta taşıma ve kulaktan kulağa oyunlarıdır. Çocukların en çok zorlandıklarını söyledikleri oyunlar tekrar sırasına göre saklambaç $(n=5)$, sek sek $(n=3)$, yağ satarım $(n=3)$ ve lastik atlama $(n=3)$ olarak belirlenmiştir.

Çocuklara bu oyunları oynamakta zorlanmalarının nedeni sorulduğunda, oyunların oynanış şekillerinde zorlandıklarını belirttikleri görülmüştür. Bazı çocukların ifadelerinden örnekler aşağıda verilmiştir.

Ç: 5 Taş. Taşları havaya atıp yakalamakta zorlandım.

Ç: Saklambaç. Çünkü saklanması zor.

Ç: Bezirganbaşı. Çünkü eğilerek geçmek çok zor.

Ç: Lastik atlama. Çünkü atlamak zor.

Ç: Çelik çomak. Çünkü çomağı atmakta zorlandım.

Ç: Sek sek. Çünkü zıplarken hep çizgilere basıyorum.

Ç: Aşık vurma. Denk getiremiyorum.

Zorlandıkları oyun sorusunun hemen akabinde sorulan "neden" sorusu, oyunu neden sevdikleri sorusunda olduğu gibi analiz düzeyinde cevabın verilmesini gerektiren bir sorudur. Çocukların bu soruya cevap verdikleri cevaplar, millî oyunların oynanış şeklini anladıklarını ve oyun içinde hangi konuda zorlandıklarını açıklayabildiklerini göstermektedir.

\section{(iv) Çocukların aileleri ile oynadıkları millî oyunlar}

Çocukların aileleri ile oynadıkları millî oyunlar sorulduğunda beş yaş grubu çocukların 10 farklı millî oyun adı söylediği görülmüştür. Bu oyunlar, 5 taş, 3 taş, saklambaç, misket, evsiz tavşan, sek sek, körebe, lastik atlama, yağ satarım, aşıktır. Çocuklardan bir tanesi millî oyunlar arasında yer almayan "çatlak patlak" oyununun adını söylemiştir. Çocukların çoğunluğu aileleriyle saklambaç $(n=6)$ ve misket $(n=6)$ oynadıklarını belirtmiştir.

Dört yaş grubu çocuklara baktığımızda aileleriyle 10 farklı millî oyun oynadıklarını belirttikleri görülmüştür. Bu oyunlar, topaç, saklambaç, yakan top, istop, kedi sıçan, bezirganbaşı, yağ satarım, evsiz tavşan, körebe, mendil kapmacadır. Çocuklardan dördü aileleriyle hiç millî oyun oynamadıklarını ifade etmiştir. Çocuklar tarafından en fazla tekrar eden oyun ise saklambaç $(n=10)$ oyunu olmuştur.

\section{SONUUÇ, TARTIŞMA VE ÖNERILER}

Araştırma sonucunda elde edilen bulgular incelendiğinde, millî oyunların okul öncesi eğitim programı kapsamında rahatlıkla verilebildiği ve çocukların kültürün önemli bir unsuru olan millî oyunlarla da çocukların gelişimlerinin desteklenebildiği görülmüştür. Millî oyunlar, matematik, Türkçe, fen, sanat, müzik gibi etkinlik çeşitleri ile bütünleştirilmiş etkinlikler halinde uygulanmış 
ve çocukların bilişsel, dil, sosyal-duygusal, fiziksel ve özbakım becerileri desteklenmiştir. Araştırmada aktarımı yapılan 38 farklı millî oyunun adının yüksek oranda çocuklar tarafından söylendiği, etkinliklerde oyunların oynanışlarının algılandığı ve uygulama sürecinde çocukların oyunları isteyerek ve eğlenerek oynadığı gözlenmiştir. Okul öncesi dönemde, bir uygulamanın çocuklar üzerindeki etkisini gösteren önemli yollardan birisi çocuklara duygu ve düşüncelerinin sorulmasıdır. Bu bağlamda yapılan gözlemin yanı sıra çocukların verdikleri cevaplarla da millî oyunların nasıl oynandığını anladıkları, deneyimledikleri ve millî oyunların çocuklar üzerinde algı oluşturduğu görülmüştür. Diğer bir ifade ile kültürel mirasımız olan oyunlarımızın gelecek nesil olan çocuklarımıza aktarımının gerçekleştiğini ve millî oyunların aktarımının çocukların duygu ve düşünceleri üzerinde etkili olduğu söylenebilmektedir.

Çocuklara geçmişte oynanan oyunların neler olabileceği sorulduğunda dört yaş grubunun (\%84) beş yaş grubuna (\%63) göre daha fazla millî oyunun adını belirttikleri görülmüştür. Aynı zamanda beş yaşa göre dört yaşında olan çocuklar üzerinde millî oyunların aktarımının daha etkili olduğu görülmüştür.

Yavuzer (2003), medya ve değişen toplumun bir getirisi olarak çocuklarda ekran ve bilgisayar bağımlılı̆ının meydana geldiğini, bunun sonucu olarak da sokak oyunlarının azaldığını belirtmiştir. Artar ve arkadaşları (2002) yaptıkları araştırmada sonucunda çocukların oynadığı oyunların sayısının, oyun türlerinin ve grup oyunlarının gitgide azaldığı ortaya konulmuştur. Benzer araştırmalarda da kültürel oyunların sayısı ve çeşitliliğinin azalmaya ve yavaş yavaş yok olmaya başladığını göstermektedir (Başal, 2007; Akçay ve Özcebe, 2012; Koçyiğit ve BaydilekBaşara, 2015; Gündoğdu ve diğerleri, 2016). Brock arkadaşları (2013) 3- 6 yaş çocuklarına nitelikli oyun desteği sağlanması üzerine yaptığı çalışma sonucunda çocukların bir sonraki eğitim kademesi olan ilkokula daha hazır hale geldiğini, ancak bunun sağlanmabilmesi için ise öğretmenlerin oyunla öğretim yöntemini kullanmaları gerektiğini belirtmiştir. Yapılan araştırmada, verilen eğitim sonucunda millî oyunların gelecek nesillere kazandırılabildiği, dolayısıyla da oyunların yok olma riskinden kurtarılabildiği görülmektedir. Bu sonuç aynı zamanda kültürel mirasa sahip çıkma ve korumada eğitimin en doğru yol olduğunun da göstergesi olmuştur.

Çocukların en çok sevdikleri oyunlar değerlendirildiğinde, beş yaş grubu çocukların misket, dört yaş grubu çocukların ise saklambaç oyunlarını daha fazla tekrar ettikleri görülmüştür. Tuğrul ve arkadaşlarının (2014) dede ve nineler ile torunların oynadıkları oyunlar karşılaştııılığı araştırmalarında dede ve ninelerin saklambaç, sek sek ve 5 taş oyununu oynadıkları, torunların ise bilgisayar, telefon, savaş ve top oyunları oynadıkları ortaya konulmuştur. Kuşaklar arasında görülen bu fark günümüzde çocukların kültürel oyunları oynamadığının önemli bir göstergesidir. Araştırmada çocukların geçmişte dedelerin ve ninelerin oynadıkları millî oyunları oynamayı sevdiklerini ifade etmeleri, kuşaklar arası kopukluğun da önüne geçilmiş olunduğunu göstermektedir.

Sevdikleri oyunları neden çok sevdikleri sorulduğunda ise çoğunlukla eğlenmiş olmaları çocuklar tarafından nedeni olarak belirtilmiştir. Pilten ve Pilten (2013) çocukların oyun algısı üzerine yaptıkları araştırmada, bir etkinliğin oyun olup olmadığına karar vermede çocukların kullandıkları temel ölçütün eğlence olduğu ortaya konulmuştur. Yavuzer (2001) oyunu çocukların sonucunu düşünülmeden, eğlenmek amacıyla yaptıkları hareketler olarak tanımlamıştır. Dolayısıyla eğlenmek çocuklar için oyunla eş değer gözükmektedir. Araştırmada da çocukların eğlendikleri için oyunu sevdikleri belirtmeleri bunun en güzel göstergesi olmuştur. Kültürün yaşatılması ve gelecek nesillere aktarılmasında da eğlenme odak noktasındadır. Bu nedenle millî oyunlar, kültürel aktarımın sağlanmasında önemli bir araç olarak görülmelidir (Esen 2008). 
Çocuklar sevdikleri oyunlara yönelik ikinci önemli neden olarak oyunların oynanış şeklini ifade etmiştir. Çocukların oyunun oynanış şekli üzerine cevap vermeleri ise oyunların çocuklar tarafından kavrandığının ve uygulandığının bir göstergesidir. Bloom'un düşünme becerilerini ortaya koyan taksonomiye göre, uygulama basamağı bir becerinin bilme, kavrama düzeylerinden sonra doğrudan yaparak gösterilmesi, gerçekleştirmesi olarak tanımlanmaktadır (Bay, 2011; Aktaş, 2017). Çocukların cevaplarından oyunlar üzerinde uygulama basamağında düşünsel bir beceriye sahip oldukları söylenebilmektedir. Araştırmada oyunu neden sevdikleri sorusunun cevabı ise çocukların bir yıl süresince öğrendikleri bütün millî oyunları sevmelerinin nedenini kendi algılarında analiz etmelerini gerektirmektedir. Analiz bütünün önemsiz parçalarından önemlileri veya ilişkili kısımlarından ilişkisizleri ayırma (Bay, 2011; Aktaş, 2017) olduğuna göre araştırmada çocukların analiz düzeyinde cevap verdikleri görülmektedir. Bir diğer ifade ile analiz düzeyinde öğrenme gerçekleşmiştir.

Çocukların oynamakta en çok zorlandıkları millî oyunlar sorulduğunda 5 yaş çocuklarının beş taş oyununu, dört yaş çocuklarının ise saklambaç oyununu sıklıkla tekrarladıkları görülmüştür. Zorlanmalarının nedeni ise oyunların oynanış şekilleri olarak belirtilmiştir. Çok eski tarihlerde oynanan " 5 taş" oyunu çocukların en çok kullandığı oyun araçlarından olan taşlarla oynanan bir oyundur (Akandere, 2004) ve 5 taş oyunu dikkat ve el göz koordinasyonu gerektiren bir oyundur. Okul öncesi dönem bu becerilerin geliştiği bir dönemdir ve 5 taş oyunu bu anlamda çocukların becerilerinin gelişimini destekleyen millî bir oyundur. Beceri süreç içerisinde gerçekleştiğinden başlangıçta çocukların zorlanmaları olağandır.

Saklambaç oyunu ise ciddi bir strateji oyunudur. İyi saklanmak ve saklandığın yerden zamanında ayrılmak gerekmektedir. Bu oyun sürecinde çocuk saklanacak mekanları değerlendirmekte, değerlendirmesi sonrasında seçmekte, seçtiği mekanda en uygun şekilde saklanmakta, saklandığı alandan ebenin uzaklığını ve sobeleme yerine kendi yakınlığını hesap ederek sobeleme için alandan ayrılmaktadır. Basit bir oyun gibi görülse de aslında çok iyi planlama gerektiren bir oyundur. Dört yaş grubunun zorlandıkları durum aslında onların gelişmekte olan düşünme becerileri ile doğrudan ilgilidir. Düşünme becerileri geliştikçe oyuna yönelik stratejileri de gelişecektir.

Çocukların aileleriyle oynadıkları millî oyunlar sorulduğunda her iki yaş grubu da 10 farklı millî oyunun adını söylemiştir. Araştırmanın uygulama sürecinde ailelerin çocuklarıyla millî oyunları oynamış olmaları, onların millî oyunlara yönelik farkındalık oluşturduklarının bir göstergesidir. Saklambaç oyunu her iki yaş grubunda da sıklıkla ailelerin çocuklarıyla oynadıkları oyun olarak görülmektedir. Ayrıca beş yaş grubunda misket oyunu da sıklıkla oynanan oyun olarak belirtilmiştir. Bu soruda çocukların aileleriyle oynadıkları bir çok oyunun içinden millî olan oyunları ayırabildikleri görülmektedir. Verilen cevaplar, çocukların millî oyun kavramını, bir diğer ifade ile geçmişte oynanan oyunları kavramış olduklarını göstermektedir.

Oyun sadece toplumun kültürünü kazandırmamaktadır. Toplumda halihazırda aktif olarak oynanan çocuk oyunları aynı zamanda toplumun kültürünü, dolayısıyla da toplumu etkilemektedir. Bu bağlamda oyun ve kültür arasında çift yönlü bir etkileşim vardır. (Yıldızbaş ve Apaydın, 2002). Tuğrul ve arkadaşlarının (2014) kuşaklar arasında oyunların değişimini incelediği araştırmasında günümüzde çocukların bilgisayar oyunlarını sıklıkla oynadıklarını ve kuşaklar arasında oyun tercihlerinin farklılaştığını ortaya koymuştur. Aslında çocukların oyunlarındaki bu farklılaşma ailenin de bize değişim içinde olduğunun bir göstergesidir. Kültürün en önemli aktarım alanı olan aile, millî oyunların aktarımını yeterli düzeyde gerçekleştirememektedir. Günümüzde çocukların sanal ortamlarda; şiddet, bencillik, çıkarcılık ve acımasızlık gibi kavramların ön plana çıkarıldığı oyunları oynamalarının gelecekte nasıl bir tehlike oluşturacağının hem aileler hem de eğitimciler tarafında görülmesi ve önlem alınması gerekmektedir. Bu önlem millî oyunların hatırlanması ve yeniden oynanarak hayata geçirilmesi ile mümkün olacaktır (Bay, 
Turan ve Bay, 2015). Yapılan araştırmada millî oyunların eğitim süreci içinde aktarımının ailelere de yansıdığı, çocukların aileleriyle millî oyunları oynadıkları görülmüştür.

Sonuç olarak yapılan araştırma okul öncesi dönemde çocukların millî oyunları bilme, kavrama ve uygulama düzeylerinde deneyimledikleri görülmüştür. Araştırma sonucunda ortaya çıkan geçmişte oynanan oyunların bilgisi, bu oyunlardan sevilen ve zorlanan millî oyunların bilgisi ve nedenine yönelik açıklamalar, ailelerle oynanan millî oyun bilgisi, kültürel mirasımız olan oyunlarımızın çocuklar üzerinde etkili olduğunu ve bu sayede kültürel aktarımın yapılabildiğini göstermektedir. Millî oyunların kazandıııması ile sadece çocukların ait olduğu toplumun bir bireyi olarak kültürel gelişimlerini değil, aynı zamanda okul öncesi eğitim programı kapsamında uygulanarak çocuğun diğer tüm gelişim alanlarının da desteklenebildiğini göstermektedir.

Toplumu bir bütün kılan ve devamlılığını sağlayan kültürün gelecek nesillere aktarımının tesadüflere bırakılmaması ve millî eğitim politikasının temel unsurları arasında yer alması gerekmektedir. Bu bağlamda eğitimcilere önemli görevler düşmektedir. Bilhassa eğitimin ilk kademesi olan ve çocuğun kişiliğinin oluşmaya başladığı okul öncesi eğitim, kültür gelişimi açısından kritik bir evredir. Özellikle bu evrede görev alan eğitimcilerin küreselleşme ve teknolojinin etkisini en aza indirecek tedbirler alması gerekmektedir. Bu bağlamda;

- Okul öncesi eğitim programı içinde kültürel aktarımın önemli bir unsuru olan oyunların aktarılmasının gerekliliğinin vurgulanması ve gerekli açıklamaların yapılması;

- Eğitimcilerin doğrudan kullanabileceği etkinlik örneklerinin eğitim materyali olarak sunulmasl;

- Anaokullarında ve eğitim sürekliliği esasına dayalı olarak diğer eğitim kademelerinde millî oyunların kazandırıımasına yönelik ortak proje çalışmalarının başlatılması;

- Okul öncesi eğitimde millî oyun uygulamaların arttııımasına yönelik eğitimcilere millî oyunları ve uygulamaların anlatılacağı eğitim seminerlerinin düzenlenmesi;

- Öğretmenlik lisans programında "Millî Oyunlar" konulu ders içeriğinin oluşturulması;

- Millî oyunların gelişim alanları üzerinde etkisini ortaya koyacak derinlemesine araştırmaların yapılması önerilmektedir.

\section{KAYNAKLAR}

Akandere, M. (2004). Eğitici okul oyunları. Ankara: Nobel Yayıncılık

Akçay, D., \& Özcebe, H. (2012). Okul öncesi eğitim alan çocukların ve ailelerinin bilgisayar oyunu oynama alışkanlıklarının değerlendirilmesi. Çocuk Dergisi, 12(2), 66-71.

Aktaş, E. (2017). Öğretmen adaylarının farklı metin türlerine yönelik soru sorma becerilerinin yenilenmiş bloom taksonomisine göre değerlendirilmesi. Electronic Turkish Studies, 12(25), 99-118.

Akyüz, Y. (2016). Eğitimin kültür ve uygarlıkları geliştirme ve yeni nesillere aktarma işlevi. Türkiye Eğitim Dergisi, 1(1), 1-18.

Anılan, H., Girmen, P., Öztürk, A., \& Koçkar, M. T. (2004). Geleneksel çocuk oyunlarının eğitimsel değeri. Omep Dünya Konsey Toplantısı ve Konferansı 3-5 Ekim 2003 (ss.2-10). Kuşadası, Türkiye.

Aral, N. (2000). Çocuk gelişiminde oyunun önemi. Çağdaş Eğitim, 25(265), 15-17.

Artar, M. (2004). Okul öncesi öğretmenlerinin çocukların oyun hakkına ilişkin tutumları, B. Onur ve N. Güney (Ed.), Türkiye'de çocuk oyunlarl: Araştırmalar (ss. 84-94). Ankara: Ankara Üniversitesi Çocuk Kültürü Araştırma ve Uygulama Merkezi Yayınları. 
Artar, M., Onur, B., \& Çelen, N. (2002). Çocuk oyunlarında üç kuşakta görülen değişimler. Çocuk Forumu, 5(1), 35- 39.

Başal, H. A. (2007). Geçmiş yıllarda Türkiye'de çocuklar tarafından oynanan çocuk oyunları. Uludağ Üniversitesi Eğitim Fakültesi Dergisi, 20(2), 243-266.

Bay, N. (2011). Öğretmenlerine verilen soru sorma becerisi ögretiminin etkisinin incelenmesi. Doktora Tezi, Gazi Üniversitesi, Ankara, Türkiye.

Bay, D.N., Turan, S., \& Bay, Y. (2015). Türk Dünyasında Çocuk Oyunları: Bir Saha Çalışması. I. Uluslararası Türk Dünyası Çocuk Oyun ve Oyuncakları Kurultayı 14-17 Mayıs 2015 (ss. 175-185). Eskişehir Osmangaz Üniversitesi, Eskişehir, Türkiye.

Bayat, B. (2003). Bireylerin benlik algııı (benlik tasarımları) sistemi ve bu sistemin davranışları üzerindeki rolü. Kamu Dergisi 7(2), 123-137.

Bayrak, M. (1998). Geleneksel mahalli çocuk oyunları -Tokat ili örneği. Yüksek Lisans Tezi, Gazi Üniversitesi, Ankara, Türkiye.

Büyüköztürk, Ş., Çakmak, E. K., Akgün, Ö. E., Karadeniz, Ş., \& Demirel, F. (2017). Bilimsel araştırma yöntemleri (18. Baskı). Ankara: Pegem Yayınları.

Brock, A., Dodds, S., Jarvis,P., ve Olusoga,Y. (2013). Persfectives On Play: Learning For Life. New York: Pearson Education Limited.

Brooker,L. (2010). Play and learning in the early years. In P. Broadhead, J. Howard and E. Wood (Eds). Learning to play in a cultural context (pp.27-43). London, Sage Publications.

Cirhinlioğlu, F. G. (2001). Çocuk ruh sağlığı ve gelişimi. Ankara: Nobel Yayınclık.

Cengiz, S. A. (1997). Karadeniz Ereğli örneğinde çocuk oyunlarının halk bilim açısından değerlendirilmesi, B. Onur (Ed.), Çocuk Kültürü, I. Ulusal Çocuk Kültürü Kongresi Bildirileri (ss. 441-476). Ankara: Ankara Üniversitesi Çocuk Kültürü Araştırma ve Uygulama Merkezi Yayınları.

Çolak, F. (2009). Geleneksel Kayseri çocuk oyunları ve halkbilimsel incelemesi. Konya: Kömen Yayınları.

Dansky, J. L. (1999). Play. In M. Runco \& S. Pritzker (Eds.), Encyclopedia of creativity (pp. 393-408). San Diego: Academic Press.

Durualp, E., \& Aral, N. (2010). Altı yaşındaki çocukların sosyal becerilerine oyun temelli sosyal beceri eğitiminin etkisinin incelenmesi. Hacettepe Üniversitesi Eğitim Fakültesi Dergisi, 39, 160-172.

Esen, M. A. (2008). Geleneksel çocuk oyunlarının eğitimsel değeri ve unutulmaya yüz tutmuş ahıska oyunları. Uludağ Üniversitesi Eğitim Fakültesi Dergisi, 21(2), 357-367.

Fırat, H. (2013). Çocuk oyunlari-eğitim ilişkisi: Bezirgan başı örneği. Electronic Turkish Studies, 8(13), 885896.

Fromberg, D.P.. \& Bergen, D. (2006). Introduction. In D.P. Fromberg and D. Bergen (Eds) Play from birth to twelve: Contexts, perspectives and meanings. New York: Routledge.

Girmen, P. (2012). Eskişehir folklorunda çocuk oyunlari ve bu oyunlarin yaşam becerisi kazandirmadaki rolü. Milli Folklor, 24(95), 263-273.

Gökşen, C. (2014). Oyunların çocukların gelişimine katkıları ve Gaziantep çocuk oyunları. Atatürk Üniversitesi Türkiyat Araştırmaları Enstitüsü Dergisi, (52), 229-259.

Göncü, A., Tuermer, J., \& Johnson, D. (1999). Children's play as cultural activity, A. Göncü (Ed.), Children's Engagement in the World (ss. 148-167). New York, NY: Cambridge University Press.

Gözalan, E., \& Koçak, N. (2014). Oyun temelli dikkat eğitim programının 5-6 yaş çocukların kelime bilgi düzeylerine etkisinin incelenmesi. KMÜ Sosyal ve Ekonomik Araştırmalar Dergisi 16(2), 115-121.

Gündoğdu, Z., Seytepe, Ö., Pelit, B. M., Doğru, H., Güner, B., Arıkız, E., Akçomak, Z., Kale, B., Moran, ì., Aydoğdu, G., \& Kaya, E. (2016). Okul öncesi çocuklarda medya kullanımı. Kocaeli Üniversitesi Sağık Bilimleri Dergisi, 2(2), 6-10. 
Güneş, F. (2015). Oyunla öğrenme yaklaşımı. Electronic Turkish Studies, 10(11), 773-786.

Kaya, A. (2010). Oyun müdahale programının 3-5 yaş arasındaki özel gereksinimli çocukların bilişsel becerilerinin desteklenmesindeki etkililiğinin incelenmesi. Yüksek Lisans Tezi, Ankara Üniversitesi, Ankara, Türkiye.

Kaytez N., \& Durualp E. (2014) Türkiye'de okul öncesinde oyun ile ilgili yapılan lisansüstü tezlerin incelenmesi. Uluslararası Türk Eğitim Bilimleri Dergisi, 2(2), 110-122.

Kerkez, F., (2002). Çocuklarını anaokuluna gönderen ailelerin oyun ve spora yönelik tutumları (Trabzon örneği). Marmara Üniversitesi Spor Araştırmaları Dergisi, 6 (16), 1-16.

Koçyiğit, S., \& Baydilek-Başara, N. (2015). Okul öncesi dönem çocuklarının oyun algılarının incelenmesi. Yüzüncü Yıl Üniversitesi Eğitim Fakültesi Dergisi, 12(1), 1-28.

Kuru, O., \& Köksalan, B. (2012). 9 yaş çocuklarının psiko-motor gelişimlerinde oyunun etkisi. Cumhuriyet International Journal of Education, 1(2), 37-51.

Mahiroğullari, A. (2005). Küreselleşmenin kültürel değerler üzerine etkisi. Sosyal Siyaset Konferansları Dergisi, 50, 1276-1288.

Malinowski B. (2000). Büyü, bilim ve din (Saadet Özkal, trans.). İstanbul: Kabalcı Yayımları.

MEB, (2013). Okul Öncesi Eğitim Programı. Ankara: MEB Basımevi.

Neuliep, J.W. (2012). Intercultural communication: A contextual approach (5thEd.). Thousand Oaks, CA: Sage Publications.

Oksal, A. (2004). Kuşaklararası Oyun: Yetişkin ve çocuk kültürü arasında bir köprü, B. Onur ve N. Güney (Ed.), Türkiye'de çocuk oyunları: Araştırmalar (ss. 123-128). Ankara: Ankara Üniversitesi Çocuk Kültürü Araştırma ve Uygulama Merkezi Yayınları.

Onur, B., \& Güney, N. (2004). Türkiye'de çocuk oyunlarl: Araştırmalar. Ankara: ATAUM Yayınları, 12.

Öncü, Ç. E., \& Ünlüer, Ö. E. (2014). Erken çocukluk dönemindeki çocuklar için oyun. Ankara: Kök Yayıncılık.

Özdemir, N. (2006). Türk çocuk oyunlarl. Ankara: Akçağ Yayınları.

Özdemir, S. (2015). Kıbrıs'taki geleneksel çocuk oyunlarının kübik öğretim programı temelinde okul öncesi eğitim ve bilişsel gelişim kazanımlarıyla ilişkilendirilmesi. Turkish Studies, 10(11) 1217-1230.

Özden Gürbüz, D. (2016). Geleneksel çocuk oyunlari ve eğitimsel işlevleri: emirdağ örneği. Electronic Turkish Studies, 11(14), 529-564.

Pektaş, Ö. H. (2017). Geleneksel çocuk oyunlarinin modern eğitimde kullanilmasi. Journal of International Social Research, 10(49), 478-490.,

Pilten, P. ve Pilten, G. (2013). Okul çağı çocuklarının oyun kavramına ilişkin algılarının ve oyun tercihlerinin değerlendirilmesi. Mersin Üniversitesi Eğitim Fakültesi Dergisi, 9(2), 15-31.

Russ, S. W. (2004). Play in child development and psychotherapy: Toward empirically supported practice. Mahwah, New Jersey: Lawrence Erlbaum Associates, Inc.

Sağlam, T. (1997). Türk Çocuk Oyunlarında Ritüel Ögeler. Çocuk Kültürü, I. Ulusal Çocuk Kültürü Kongresi Bildirileri, 416-441.

Senemoğlu, N. (1994). Okulöncesi eğitim programı hangi yeterlikleri kazandırmalıdır? Hacettepe Üniversitesi Eğitim Fakültesi Dergisi, 10(10), 21-31.

Sevinç, M. (2004). Erken çocukluk gelişimi ve eğitiminde oyun. İstanbul: Morpa Kültür Yayınları.

Toksoy, A. C. (2010). Yarışma niteliği taşıyan geleneksel çocuk oyunları. Çevirimiçi Tematik Türkoloji Dergisi, 2(1), 205-220.

Tuğrul, B., Ertürk, H. G., Özen Altınkaynak, Ş., \& Güneş, G. (2014). Oyunun üç kuşaktaki değişimi. The Journal of Academic Social Science Studie, 27, 1-16. 
Türkçe Sözlük. (1998). 9. baskı. Ankara: TDK Yayınları.

Türkoğlu, B. \& Uslu, M. (2016). Oyun temelli bilişsel gelişim programının 60-72 aylık çocukların bilişsel gelişimine etkisi. Uluslararası Eğitim Bilimleri Dergisi, 3(6), 50-68.

Yardımcı, M., \& Tuncer, H. (2002). Çocuk edebiyatı. Ankara: Ürün Yayınları.

Yörükoğlu, A. (2004). Çocuk ruh sağlığı. İstanbul: Özgür Yayınları.

Yavuzer, H. (2003). Doğal harika bir tedavi: Oyun. Evde ve Okulda Mutlu Çocuk Yetiştirmenin Temelleri. İstanbul: Çocuk ve Aile Kitapları.

Yavuzer, H. (2001). Çocuk Psikolojisi. İstanbul: Remzi Kitabevi.

Yıldızbaş, F., \& Apaydın, Ş. (2002). Kültür ve çocuk oyunları ilişkisi. Abant İzzet Baysal Üniversitesi Eğitim Fakültesi Dergisi, 2(1), 96-104.

Yıldırım, A., \& Şimşek, H. (2013). Sosyal bilimlerde nitel araştırma yöntemi. (8. Baskı). Ankara: Seçkin Yayıncılık. 


\title{
A Transfusion of Culture in Preschool: National Games
}

\author{
Dr. Döndü Neslihan BAY(Academician) \\ Eskişehir Osmangazi University-Turkey \\ bayn@ogu.edu.tr
}

\begin{abstract}
The purpose of this research is to expose the effect of the national game activities, prepared to the extent of preschool education program, on children. In accordance with this purpose, subgoals were composed by the presentation of national games that children know, love playing the most, have the most difficulty playing with, and play with their families. With the execution of a new practice and research of collaborative act that includes the process of doing evaluation related to this practice, national games were practiced within the preschool education program and its effect on children was evaluated. Sixty children have participated in this research. In the process of the research, thirty-eight different national games were used during the yearlong study. The Children were interviewed and achievement of cultural transfusion is demonstrated by observation of children's desire to play the games, positive evaluation of teachers, and children's ability to usually recall the games. The following results were attained that children's most favorite games were "marbles" and "hide and seek"; the reason for them to like these games were "having fun" and the "game's mode of playing". The games they had the most difficulty with were "five stone" and "hide and seek". Children also played these games at home with their families. As results were evaluated, it was seen that national games were effective on children's attention and perception.
\end{abstract}

Keywords: National, play, culture, education, pre-school, kindergarten

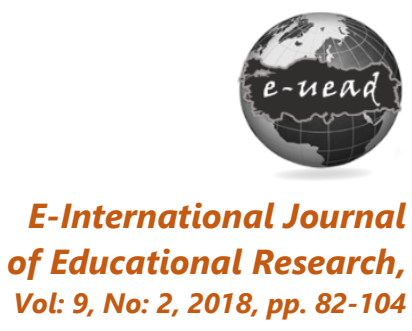

DOI: 10.19160/ijer.398721

Received: 26.02 .2018 Accepted: 03.08.2018

\section{Suggested Citation:}

Bay, D.N. (2018). A Transfusion of Culture in Preschool: National Games E-International Journal of Educational Research, Vol: 9, No: 2, 2018, pp. 82-104, DOI: 10.19160/ijer.398721 


\section{EXTENDED ABSTRACT}

\section{Introduction}

Game is an essential part of the child's life in preschool period, at the same time, it is an important cultural element that comes from past to present from generation to generation. For continuity of the existence of a society, the culture that carries the values of that society must also continue. National children games that will provide cultural continuity has a great importance to contribute to children who will form future generations, becoming an individual with values of society. Therefore, culture transfer with bringing national children games to children should not be left to chance; it is necessary to start in direct national education programs, especially in pre-school education, which is a critical stage for cultural development. In this context, how national children's games can be given to children in the preschool education program is the subject of research.

\section{Purpose}

Purpose of the research is to demonstrate the influence of the national game activities prepared within the extent of preschool education program on children. In accordance with this purpose, after the implementation of national game activities for one year, Revealing of (i) national games that children know, (ii) national games that children like, (iii) national games that children are forced to play, (iv) national games that children play with their family are constituting subobjectives.

\section{Method}

Collaborative action research has been carried out from the qualitative research varieties. Collaborative action research involves the implementation of a new application and the evaluation of this application process. In this research, after national games applied as an integrated activities with different activities such as science, math and music in the preschool education program for one year; national games applied as a game activities and the influence of national games on children has been evaluated.

60 children studying in 4 and 5 age groups participated in this research. In the research process, 38 different national games were determined and implemented every week during one year of education as integrated and game activities. During the implementation process, children's participation in the games was observed and event evaluations were taken from the teachers. Children were interviewed and 4 open-ended questions were asked in order to determine the effect of the games that an important element of the culture on children.

\section{Result}

As a result of research, firstly, the applicability of national games in the extent of preschool education program is revealed. These findings show that the cultural transfer takes place: during the application process, the observation that children were willing to play games, the positive evaluation expressions of teachers were both in written and verbalization, the expressions of children in the age of four 32 out of 38 and also the expressions of children in the age of five 24 to questions about what games played in the past might be.

When the findings obtained from other questions focusing on the effects of children were evaluated, these were observed that when children were asked about their favorite games, fiveyear-old children's repeated game was "marbles" and four-year-old children's repeated game was "hide and seek"; children stated the reasons for the likes of games as often having fun and the way of games were played; when children were asked about the most challenging games, 
five-year-old children said "jacks", four-year-old children said "hide and seek" frequently; when asked about cultural games they played with their families, both age groups expressed the name of 10 different national games.

\section{Conclusion}

As a result, it was seen that preschool children experienced the national games at the level of knowing, comprehension and application. The results of the research, the knowledge about past national games, the knowledge about national games which were popular and challenged and the explanation about the reason of these feelings indicate that games which are our cultural heritage are effective on children and in this way cultural transmission can be done. With the acquisition of national games, not only the cultural development of a society whose children belong as an individual, at the same time, it can be applied within the extent of preschool education program and all other development areas of the child can be supported.

On the other hand they stated that some problems such as the Turkish Ministry of Educational Affairs doesn't take the program into consideration and courses aren't practice oriented which have a negative effect on the efficiency of the program. 


\section{EKLER}

\section{Ek 1. Millî Oyunların Listesi}

(1) Yağ Satarım, (2) Halat Çekme, (3) Aşık Vurma, (4) Yüzük Saklama, (5) İp Oyunu, (6) Saklambaç, (7) Körebe, (8) Yakan Top, (9) Semaver, (10) Uçtu Uçtu, (11) Kedi Sıçan, (12) Yumurta Taşıma, (13) Bezirganbaşı, (14) Sek Sek, (15) 5 Taş, (16) Mendil Kapmaca, (17) Topaç, (18) Kazlar Kazlar, (19) Kuyruk Yakalama, (20) Kulaktan Kulağa, (21) Fırıldak, (22) At Yarışı, (23) Birdirbir, (24) İstop, (25) Kim Gerek, (26) Boya, (27) Çuval Yarışı, (28) Sapan, (29) Misket, (30) 3 Taş, (31) Yerden Yüksek, (32) Kızlar Kızlar Çık, (33) Çelik Çomak, (34) Lastik Atlama, (35) Köşe Kapmaca, (36) Evsiz Tavşan, (37) Köprü, (38) Şapka.

\section{Ek 2. Bütünleştirilmiş Etkinlik Planı}

\section{Körebe}

Etkinliğin Türü: Oyun- Fen Etkinliği (Bütünleştirilmiş Büyük Grup Etkinliği)

Yaş Grubu: 3-4-5 Yaş

\section{Kazanım ve Göstergeleri:}

BG: Kazanım 5: Nesne ya da varlıkları gözlemler. (Nesne/varlığın adını söyler.)

SDG: Kazanım 7: Bir işi veya göreve başlamak için kendini güdüler. (Başladığı işi zamanında bitirmek için çaba gösterir.)

MG: Kazanım 1: Yer değiştirme hareketleri yapar. (Yönergeler doğrultusunda yürür.)

DG: Kazanım 1: Sesleri ayırt eder. (Sesin kaynağının ne olduğu söyler.)

ÖZB: Kazanım 7: Kendini tehlikelerden ve kazalardan korur. (Temel güvenlik kurallarını bilir.)

\section{Milli Kazanımlarımız:}

Türk kültüründeki millî oyunları bilir.

Türk kültüründeki millî oyunları oynar.

Sözcük: Körebe

Kavramlar: Sert ve yumuşak (Duyu kavramı)

Materyaller: Dokunma kartları, müzik aletleri, sert ve yumuşak nesneler, kutu

\section{Öğrenme Süreci:}

- Çocukların halıya daire şeklinde oturmaları istenilir. Ardından Öğretmen çocuklara; "Çocuklar bildiğiniz oyunlar nelerdir? Nasıl oynanır? Peki; Körebe adında oyun biliyor musunuz? Hiç duydunuz mu? İsmi neden Körebe olabilir? Bu oyun nasıl oynatılıyordur sizce?" denir ve cevaplar alınır. (İmkân varsa körebe oyununun videosu izletilir.) "Eskiden ninelerimiz dedelerimizde bu oyunu oynamışlar." denir ve çocukların düşünceleri alınır. Daha sonra "Oyun için hangi malzeme gerekiyor? Gözlerimiz bağlandığında nası hissederiz? Hadi bir deneyelim bakalım gözlerimiz bağlanınca ne oluyor?" denir. Öğretmen çocuklardan sayışma yoluyla ebe seçer. Ebenin gözlerini bağlar. Herhangi bir müzik aletini çalarak sesin hangi müzik aletine ait olduğunu bilmesini ister. 
- Ardından seçilen başka bir çocuk tarafından ebeye "ellerine, ayaklarına dokun, başına dokun, olduğun yerde zıpla" gibi yönergeleri vererek oyun devam eder.

- Ardından bir kutuya konan sert ve yumuşak nesneler ebenin önüne konur ve ebenin elini kutuya sokarak bir nesne seçmesi istenir. Ebeye dokunduğunda neler hissediyorsun? Yumuşak mı Sert mi? Büyük mü Küçük mü? Şekli nasıl? Denilerek cevaplar alınır. Sonra çocuğun gözleri açılır ve nesnenin rengi sorulur. Ardından "El ele tutuşalım Halkaya karışalım Haydi canım sende gel oynayalım birlikte" denilerek halıda daire oluşturulur.

-Öğretmen çocuklara; "Gözlerinizi kapatarak şimdi de körebe oynayalım." denir ve öğretmen, çocuklara oyunu anlatır. "Bu oyunda müzik çalmaya başladığında ebenin etrafında dönüyoruz müzik durduğunda ebenin karşısında kim varsa ebe karşısına gelen çocuk ebenin önüne gidiyor. Ebemiz ona dokunarak onu tanımaya çalışacak." denilerek oyuna başlanır. Oyun, çocukların istedikleri doğrultusunda oynanır.

\section{Değerlendirme Soruları:}

Etkinlik sonunda çocuklara şu sorular yöneltilir;

-Gözlerin bağlanınca ne hissettin?

- Oyunumuzu nasıl oynadık?

- Gözlerin bağlanınca en çok hangi hareketi yaparken zorlandın?

-Seçtiği nesneyi nasıl tanıyabildin?

- Arkadaşını nasıl tanıdın?

Aile Katılımı: Birlikte körebe oyununu oynaması önerilir.

Uyarlama: Fiziksel yetersizliği olan çocuklarla etkinlik uygulanırken gerektiğinde fiziksel yardım sağlanarak çocuğun hareket etmesi sağlanmalıdır

Desteklenen Değerler: Kültürel mirasa sahip çıkma

Öneriler: Etkinlikte oyun sırasında oluşabilecek tehlikelere karşı gerekli önlemler alınmalıdır.

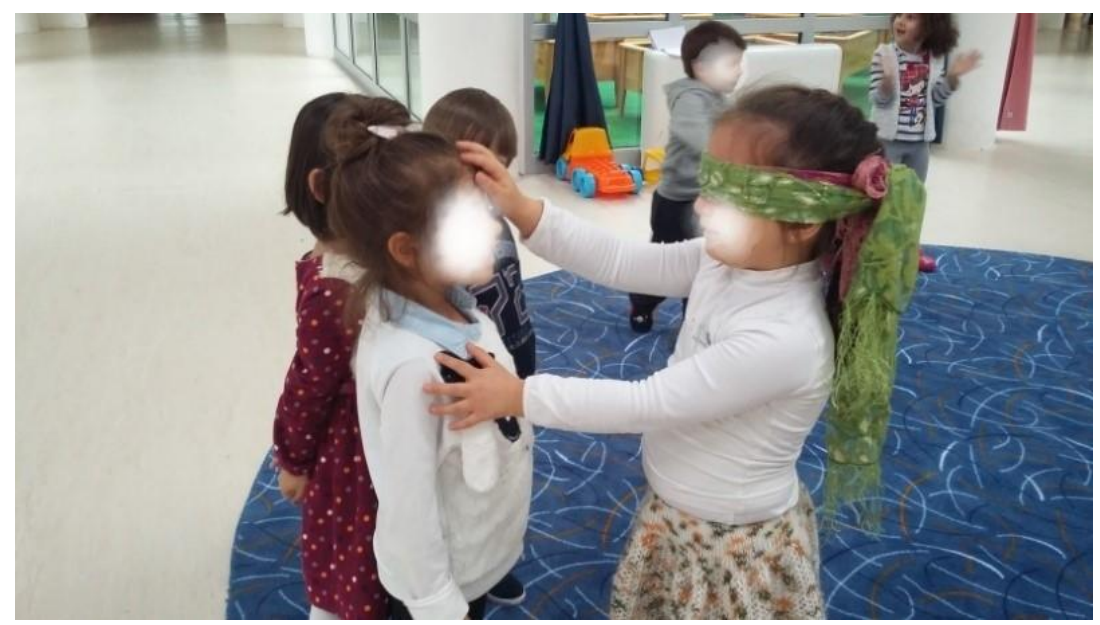

